\title{
The Influence of Emotion Based Language Instruction on Speaking and Writing Skills among
}

\section{EFL learners: An Empirical Study}

Seyyed Mohammad Reza Adel ${ }^{1}$, Hossein Najjari ${ }^{2}$, Marziyeh Farivar ${ }^{3}$, and Tahereh Heydarnejad ${ }^{4 *}$

${ }^{1}$ Associate professor, Department of English Language, Faculty of Literature and Humanities, Hakim Sabzevari University,

Sabzevar,Iran, sm.adel@hsu.ac.ir

${ }^{2}$ Assistant Professor, Department of English Language, University of Gonabad, Gonabad, Iran, naijarihossein@yahoo.com

${ }^{3}$ Assistant Professor, Department of English Language, University of Gonabad, Gonabad, Iran, farivar@gonabad.ac.ir

${ }^{4}$ English Lecturer (Ph.D. Candidate in TEFL), Department of English Language, University of Gonabad, Gonabad, Iran t.heydarnejad88@yahoo.com

Corresponding Author: Tahereh Heydarnejad, E-mail: t.heydarnejad88@yahoo.com

\section{ARTICLE INFO}

Received: November 12, 2020

Accepted: December 20, 2020

Volume: 3

Issue: 12

DOI: $10.32996 /$ ijllt.2020.3.12.25

\section{KEYWORDS}

Emotion Based Language

Learning Instruction (EBLI),

emotioncy, emotions,

productive skills, EFL students

\section{ABSTRACT}

Effective learning is the ultimate goal in every educational system, which can be achieved by considering the intertwined relationships of both cognitive and affective procedures. In line with this argument, this study intends to shed light on the impact of Emotion Based Language Instruction (EBLI) in enhancing teaching productive skills (speaking and writing) to EFL students. To do so, Quasi-Experimental Study was carried out among Iranian English as foreign language (EFL) students. The learning materials and the supplementary parts were selectively developed based on the Metric of Emotioncy designed by Pishghadam (2016). To observe the influence of EBLI, the differences in scores of pre and posttest of IELTS were statistically calculated. The results displayed a significant change in speaking and writing skills among students in the experimental group. The findings of the present study may foster EBLI implementation and increase the related knowledge in teaching foreign/second languages.

\section{Introduction}

In the fast-paced and ever-changing world, there is a considerable attentiveness in learning a second language. Language learning involves four basic skills namely, speaking, listening, reading, and writing. These skills are subdivided into two categories: productive or active skills and receptive or passive skills (Harmer, 2007). Reading and listening are considered as receptive skills, and learners are not required to produce language; they are input receiver. In contrast, speaking and writing are regarded as productive or active skills, and require the learners to produce language by themselves (Brown, 2007). Thus, speaking and writing seem more demanding and challenging for the learners, since they should transfer their competencies into performance and generate spoken or written messages. To simplify the task of learning, over the years, approaches and methods for teaching speaking and writing have gone through a myriad of changes (Brown, 2007; Nation, 2009; Nation \& Newton, 2009).

It almost goes without saying that the knowledge of vocabulary is of great importance to improve second/foreign language proficiency (Decarrico, 2001; Nation, 2009). Notably, the importance of this source of knowledge could be felt more in mastering productive skills, because without vocabulary knowledge as the building block of language, learners are not able to construct language messages. In this regard, two primary questions a language teacher faces maybe what types of vocabularies are better to teach (Pishghadam \& Shayesteh, 2017), and how to teach them effectively. Consistent with this argument,

1

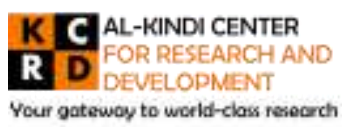

Published by Al-KindiCenter for Research and Development. Copyright (c) the author(s). This is an open access article under CC BY license (https://creativecommons.org/licenses/by/4.0/) 
Widdowson (1978) contended that the criteria for vocabulary teaching are frequency and prototype. Driven by the same concern, cultural factors (Gairns \& Redman, 1989), and learnability (McCarthy, 1990) are among the elements referred to as criteria for vocabulary teaching (Pishghadam \& Shayesteh, 2017). This underpins the fact that all of the techniques and approaches for vocabulary teaching should be well-balanced in a way that provides an appropriate situation for incidental and deliberate word learning (Baleghizadeh, 2016).

Some vocabularies may be absorbed much easier and quicker, caused by a higher level of emotioncy. The term emotioncy refers to an amalgam of emotion and frequency of the exposure to various senses (Pishghadam et al., 2016). As Pishghadam and Shayesteh (2016) put it, individuals experience different emotions in confronting a novel concept. This experience is much more highlighted in learning a second/foreign language, because L1 emotions are carried into the L2/Ln learning context by students. Furthermore, Shahian et al. (2017) claim that learning a new word is difficult when a word conveys little or no emotion. EBLI is based on emotionalism (Pishghadam, Adamson et al., 2013); in emotionalisation, the crucial role of prior emotion is emphasized. Considering the abovementioned objectives and to shed more light on this novel concept "emotioncy" in practice, this study sets out to answer the following research question:

Research Question: How does EBLI improve EFL learners' speaking and writing skills?

\section{Literature Review}

\subsection{Emotion-Based Language Instruction (EBLI)}

Emotion-Based Language Instruction (EBLI) as a novel approach to the second language (L2) acquisition assumes that various language entities (e.g., vocabularies) cause a different degree of emotion; the stronger this emotion is the faster and deeper learners can learn (Pishghadam et al., 2013). EBLI focuses on emotional competency in learners. That is, prior emotion is highlighted in EBLI. According to Pishghadam, Adamson, et al. (2013) the input should be based on vocabularies with which the students have an already-established emotional relationship. These vocabularies should be a little beyond their levels of emotioncy.

Leafing through literature, reveals three primary classifications into language learning domains: behavioristic, cognitive, and social (Brown, 2007). EBLI, the emotional movement, is a new approach to this classification, which is inspired by Greenspan's Developmental Individual-Difference Relationship-Based (DIR) model of language acquisition (1992). It highlights the critical role of early interactive emotional experiences between children and their parents or babysitter as well as its significant result in cognitive development. According to Greenspan (1992), language acquisition is an intertwined process of emotional interactions and cognitive functioning. That is, language development is a product of affective transformations enhancing children to create meaningful symbols through self-regulatory actions, communication, and social interaction (Greenspan and Lewis, 2005). In other words, affect gives flavor to whatever children do to perceive the world.

Words as the basis of language formation are not neutral; they convey different emotions. For instance, in first language acquisition words like "mommy" and "daddy" are learned quickly not just due to their high frequencies but also via the emotions (love, peace, happiness, hope, etc.) that are conveyed with these terms (Greenspan \& Shanker, 2004). Moreover, emotional experiences can be applied to semantics as well as syntax. The word, "more" for instance, reminds children of quantity and something tasty (Shanker \& Greenspan, 2005). Considering first language acquisition, children attempt to use a word referring to the unknown world while in second/foreign language learning context- just the opposite occurs (Pishghadam et al., 2017). To be more specific, in L2 learning context children lack suitable words referring to the world information transferred from L1 experiences (Greenspan, 2001). In this situation, learners make use of their previous experiences to learn new materials (Son \& Goldstone, 2009). That means they link the vocabularies of the first and the second language; the more the level of their emotioncy (emotion + frequency) is, the more natural and comfortable they can learn (Pishghadam et al., 2016). In this regard, Pishghadam, Adamson, et al. (2013) introduce three pivot constituents to the related literature: Emotioncy, Emotionalization, and Inter-emotionality, which are discussed in the following parts.

\subsection{Emotioncy}

Emotioncy, a new term coined by Pishghadam et al. (2013), refers to the sense-induced emotions caused by different language entities. According to Pishghadam (2015), emotioncy rests on the sensory constructivism theory- a recently developed dimension of constructivism, as an alternative to cognitive constructivism (Piaget, 1959) as well as social constructivism (Vygotsky, 1978). Emotioncy refers to the amalgamation of emotion and frequency of the emotions, which are evoked by the senses (Pishghadam et al., 2016). Based on the concept of emotioncy, some entities are learned easier and faster due to being 
exposed to different senses. To expand this horizon, Pishghadam (2015) posits emotioncy on a continuum: null, auditory, visual, kinesthetic, inner, and arch emotioncies. According to this figure, emotioncy can range from Avolvement (null emotioncy), to Exvolvement engaging learners from outside (auditory, visual, and kinesthetic emotioncies), and eventually to Involvement engaging learners from inside (inner and arch emotioncies). In this vein, Pishghadam (2015) grouped learners into three: avolved (null emotioncy), exvolved (auditory, visual, and kinesthetic emotioncies), and involved (inner and arch emotioncies). Emotioncy should be of utmost focus in the realm of education due to its role in joining emotion, cognition, world knowledge, and schemata needs. In this regard, Pishghadam (2016) introduces the educational emotioncy pyramid (figure1), magnifying the role of senses in the educational system. As Pishghadam (2016) puts it, learners are in a state of disequilibrium (null emotioncy) in the beginning and their first learning gained through the sense of hearing (auditory sense) as teachers start teaching through talking about the subject matter. With audio-visual information such as power point slides, and short movies, learners ' sense of sight besides hearing is involved. Entangling senses such as touch, movement, sight, and hearing (kinesthetic emotioncy level) in activities like role plays, enable learners to comprehend new meanings. Then, by providing different autonomous tasks, learners move a step forward (inner emotioncy level) and have the chance to experience reality. The tip of educational emotioncy pyramid- arch emotioncy- facilitates understanding different layers of meanings.

Figure 1: Educational emotioncy pyramid. Adapted from Pishghadam (2016)

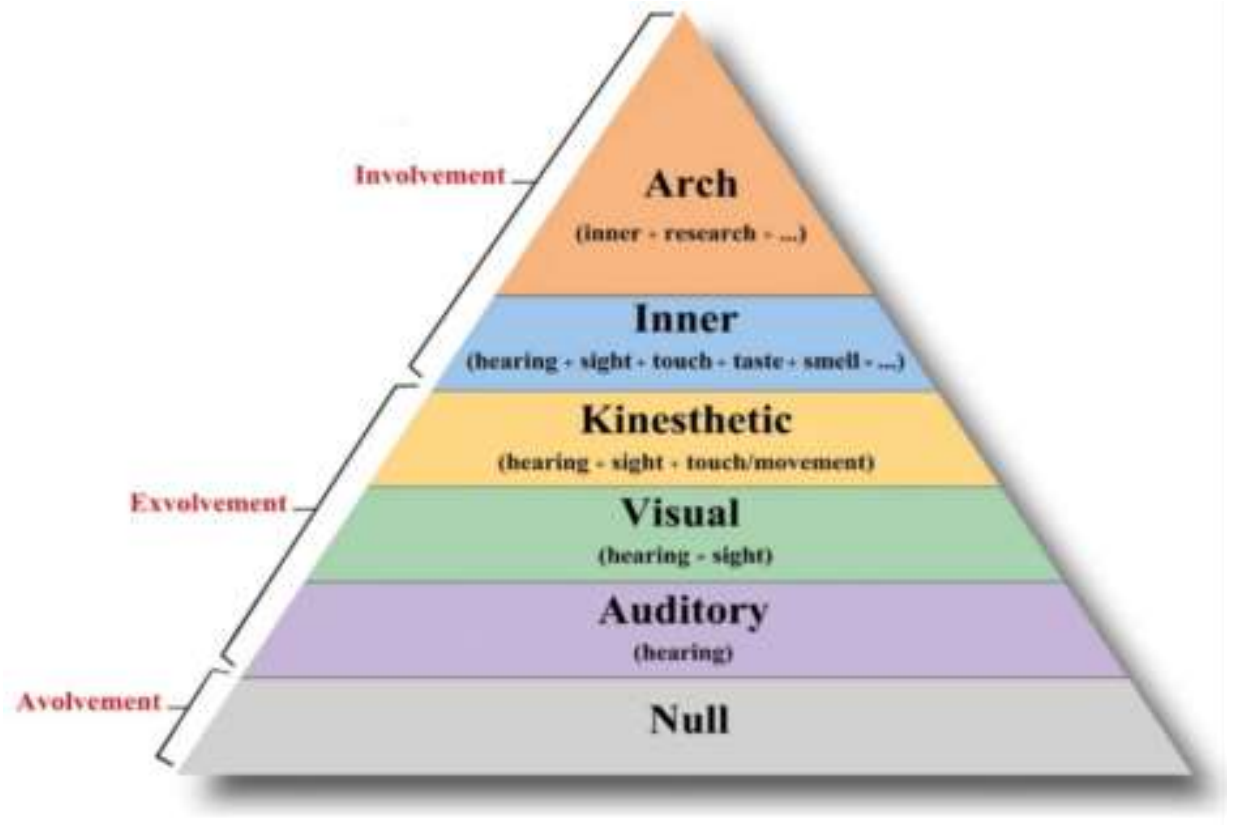

\subsection{Emotions and Teaching Productive Skills}

In the era of technology, learning a new language is an indispensable component of each person's life. Mostly, second/foreign language learning happens in academic settings such as schools and language institutes. Classrooms as the center of the academic world are emotional places (Pekrun, 2014) influencing learners' performance, identity development, motivation, and success (Schutz \& Pekrun, 2007). The advances in the humanistic approaches (Mendez Lopez and Pea Aguilar, 2013) provide a new horizon in the realm of education and, in turn, leading to significant attention to emotional states and affective factors. This is due to the fact that, emotions are among the most influential factors in the development and effectiveness of teaching and learning. Teachers, as the center of educational systems, are like a bridge between knowledge and the learners (Heydarnejad, Hosseini Fatemi, \& Ghonsooli, 2017). While teaching, they are exposed to various pleasant and unpleasant emotions. Effective teachers are those who are capable of regulating their emotions; they are mostly motivated teachers. Motivation immunizes language teachers productively which in turn enhances their effectiveness and promotes their students' achievement.

Considering learners' emotions, Ismail (2015) emphasized the salient function of both positive and negative emotions in their processes of learning and final achievement. Furthermore, Méndez Lopez and Pea Aguilar (2013) found that both positive and negative emotions influence foreign language learners' motivation. From another perspective, positive moods improve learners' performances in processing information (Febrilia et al., 2011), and enhances retrieval of long-term memory (Isen \& 
Patrick, 1983). In this respect, Pishghadam, Adamson, et al. (2013) claim that EBLT facilitates learning by entangling emotincy; the stronger it is, the better the conclusion will be.

Speaking and writing are called productive skills because learners are responsible for producing language themselves (Harmer, 2007). Capability in these skills is due to many factors such as knowledge of vocabulary, grammar, discourse, culture, as well as sociolinguistics (Chastain, 1998). Speaking is supposed to be the product of choosing suitable vocabulary and grammatical structure to express the intended meaning. Writing, the next productive skill depends on many factors. This challenging language skill requires linguistic knowledge, grammar, vocabulary, and thinking strategies (Yavuz-Erkan and iflazoğlu-Saban, 2011). In the same vein, Hidayati (2018) refers to external and internal challenges in teaching English writing skill. The external challenges can be teaching facilities, the class condition and time while the internal ones include motivation, reading habits of the students, native language interference, and linguistic competence. In addition, McLeod (1987) described writing as an emotional and cognitive activity. Since "No one is a 'native speaker' of writing" (Leki, 1992, p. 10), writing is to be assumed as an intimidating task both for native as well as for non-natives, in particular EFL learners (Cheung, 2016).

A cursory look at the literature shows a growing attentiveness toward the momentous role of emotions in language learning success in recent years. For instance, Pishghadam (2009) examined the influence of emotional and verbal intelligence on the achievement of English learners. The result of this study demonstrated that emotional intelligence is a subsidiary in learning different skills, especially, productive ones. In another research, Gupta and Woldemariam (2011) studied the effects of motivation and attitudes on the use of the writing strategy in an EFL environment. Their findings showed that learners' high motivation resulted in a high level of confidence, and, consequently a positive attitude towards using writing strategies. Besides, emotional intelligence enhancement influences on developing speaking skill in EFL learning settings were examined by Ebrahimi, Khoshsima, Zare Behtash, and Heydarnejad (2018). Based on this research, significant improvement in speaking is achieved by considering the role of emotional intelligence in improving speaking ability. Also, in another study by Jajarmi and Pishghadam (2019), the effect of EBLI on the long-term memory (LTM) vocabulary retention of Iranian EFL learners were investigated. Their findings show remarkable progress in cognition and memory enhancement due to the crucial role of senses in learning.

\section{Methodology}

The current research was designed in the 'Quasi-Experimental Study' design. A pre and post-test of IELTS were utilized to detect the development of the university students both at the beginning and at the end of the experiment in the educational year during which EBLI has been applied to teaching productive skills.

\subsection{Participants}

The participants of the present study composed of 62 Freshmen EFL learners studying at the University of Gonabad, a city in Northeast of Iran. It is assumed that participants are almost at a similar level of English competence because they are screened based on a national university entrance exam. Nevertheless, to ascertain the homogeneity of proficiency and to get a more profound insight, the researchers administered an Interchange Placement Test at the beginning of this research.

The profile of the participants goes as follows: Their age varied from 18 to 21 . The experimental group comprised 32 learners (13 male and 19 female); in the control group, there were 13 males and 17 females. The students in the experimental group majored in English Literature, while the control group comprised learners who majored in TEFL. Based on the participants' confirmation, none of them had attended conversation classes before. Thus, the proficiency of the participants was similar at the beginning of the study.

\subsection{Instruments}

IELTS test was utilized for pre and posttest of productive skills (speaking and writing skills). Then, to ensure the reliability of the scores, they were rated by three raters. Finally, the average score for each student was considered. To test the proficiency of the students, Interchange Placement Test was used, and for pre and post-test IELTS test was utilized. Also, the Metric for Measuring Emotioncy (Pishghadam, 2016, figure 2\& 3) was applied to adopt vocabularies based on learners' emotioncy. This scale contains three parts. The sense facet (consisted of null $=0$ point, auditory $=1$ point, visual $=2$ points, kinesthetic $=3$ points, inner $=4$ points, and arch $=5$ points), the emotion facet (in a form of a 5-point Likert scale, considering learners' feelings toward the hypothesized situation), and the frequency facet which intended to assess learners' amount of exposure to the situation. 
Figure 2: Emotioncy levels. Adapted from "Emotioncy in Language Education: From Exvolvement to Involvement" by $R$. Pishghadam, 2015, October, Paper presented at the 2nd Conference of Interdisciplinary Approaches to Language Teaching, Literature, and Translation Studies. Iran

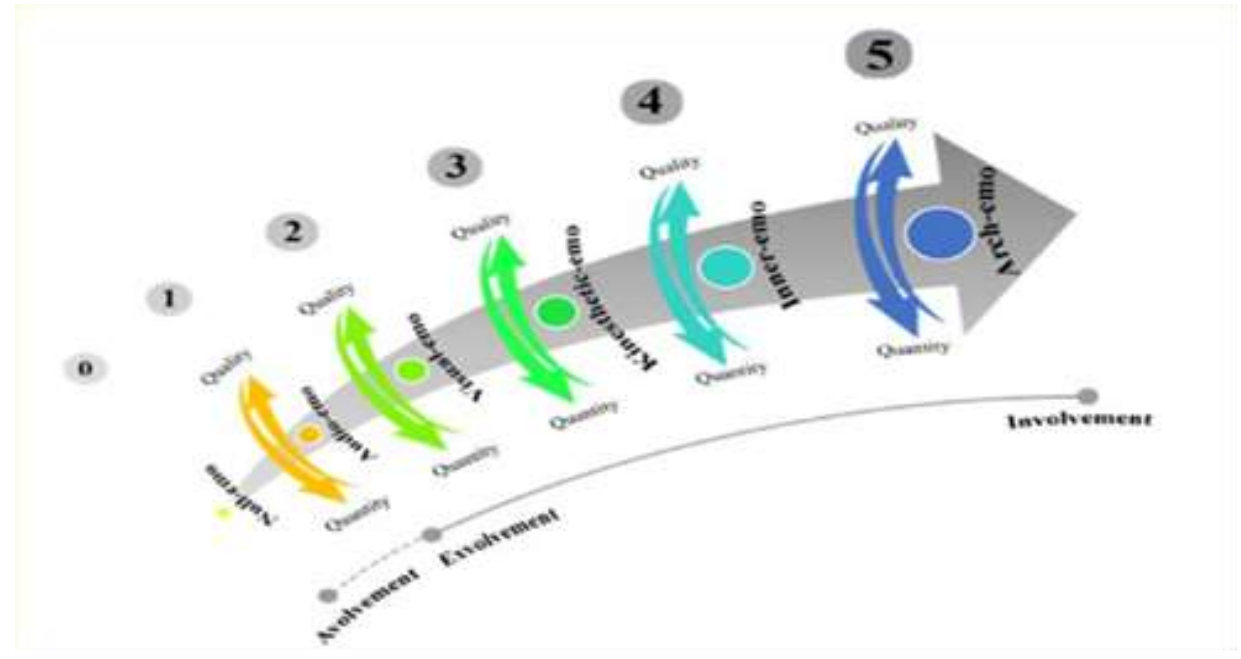

Figure 3

A Metric for Measuring Emotioncy. Adapted from "Emotioncy, extraversion, and anxiety in willingness to communicate in English" By Pishghadam, the 5th International Conference on Language, Education, and Innovation. England: London, 2016.

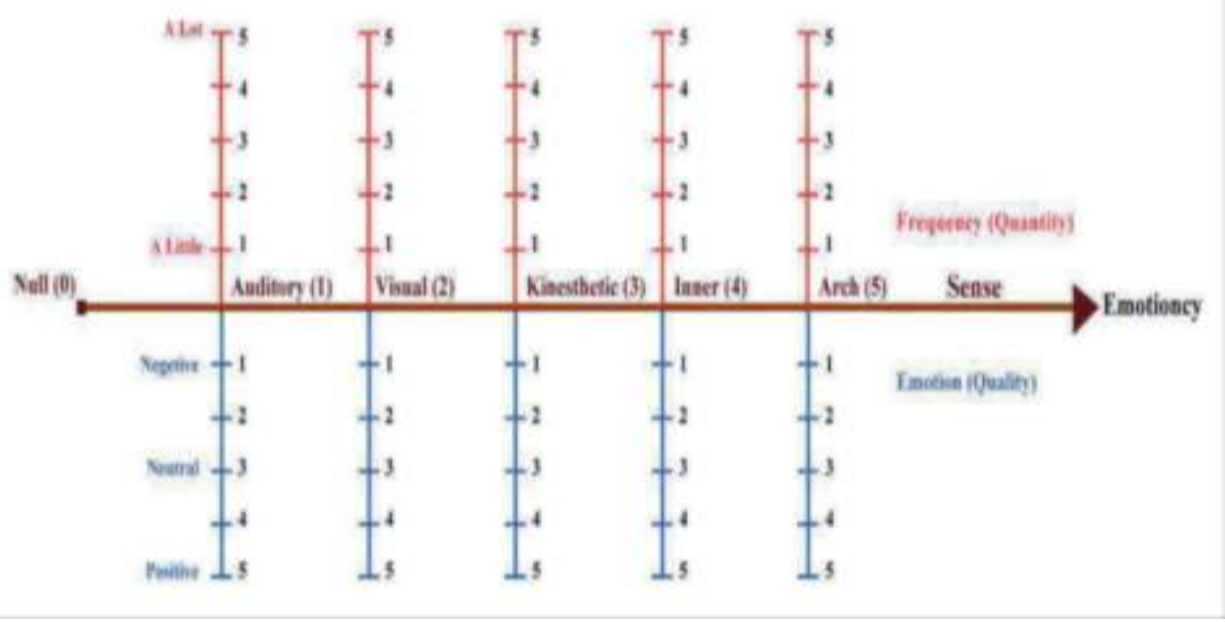

Pishghadam (2015) claims that emotioncy extends on a grading order of null, auditory, visual, kinaesthetic, inner, and arch emotioncies. According to the concept of emotioncy, learners repeat and remember vocabularies as they recall some feelings and emotions for them. So, to calculate emotioncy score, the sense score is multiplied by the summation of emotion and frequency scores (Pishghadam \& Abbasnejad, 2017).

\subsection{Procedure}

This study was conducted at the University of Gonabad, Khorasan-Razavi province, during one educational year (2018-2019). To ensure the homogeneity of the learners, the interchange placement test was administered by the researchers of this study. Then, to estimate the university students' abilities in speaking and writing skills (productive skills) they participated in the IELTS test carried out by researchers. Next, the participants were acquainted with the Metric for Measuring Emotioncy and how to use it. Also, some instruction was given on emotioncy and how to facilitate their learning by the help of emotions evoked by senses. During the two semesters, teaching was done based on Emotion Based Language Instruction in the experimental group. To do so, the teacher provided many emotional words, expressions, collocations, and idioms in selected or developed passages 
with emphasis on emotional experiences, conveyed from their L1. Learners in the control group received regular instruction and no modifications were applied on their books.

\section{Results}

In the following, descriptive statistics for the experimental and control groups are presented.

Table 1: Descriptive Statistics

\begin{tabular}{llllll}
\hline $\begin{array}{llll}\text { Groups } \\
\text { Control }\end{array}$ & & Speaking.pre & Speaking.post & Writing.pre & Writing.post \\
\cline { 1 - 4 } & $\mathrm{N}$ & 30 & 30 & 30 & 30 \\
& Mean & 5.00 & 5.15 & 5.00 & 5.06 \\
& Std.Deviation & .60 & .54 & .65 & .61 \\
& Variance & .36 & .29 & .43 & .37 \\
& Minimum & 4.00 & 4.00 & 4.00 & 4.00 \\
& Maximum & 6.00 & 6.00 & 6.00 & 6.00 \\
\hline Experimental & & & & & \\
& $\mathrm{N}$ & 32 & 32 & 32 & 32 \\
& Mean & 4.95 & 5.51 & 4.98 & 5.35 \\
& Std.Deviation & .52 & .49 & .56 & .51 \\
& Variance & .28 & .25 & .31 & .26 \\
& Minimum & 4.00 & 4.50 & 4.00 & 4.50 \\
& Maximum & 6.00 & 6.00 & 6.00 & 6.00 \\
\hline
\end{tabular}

As indicated in Table 1. the range of scores in pre and post-test of speaking skill for the control group are as follows: 4.00 to 6.00 and 4.50 to 6.00 , respectively. In the writing test, the range of scores of the control group was from 4.00 to 6.00 . For speaking and writing of the experimental group, the same ranges were observed. Although descriptive statistics results displayed significant improvement from pretest to posttest for the experimental group, to test the statistical significance of the findings independent samples t-test was run. To check the normality of the data Kolmogorov-Smirnov test was run (Table 2).

Figure 4: Comparing Speaking Skill in Control and Experimental Group

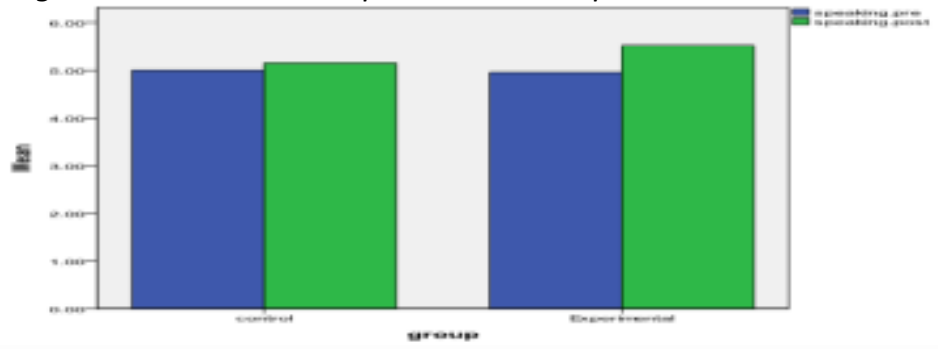

Figure 5: Comparing Writing Skill in Control and Experimental Group

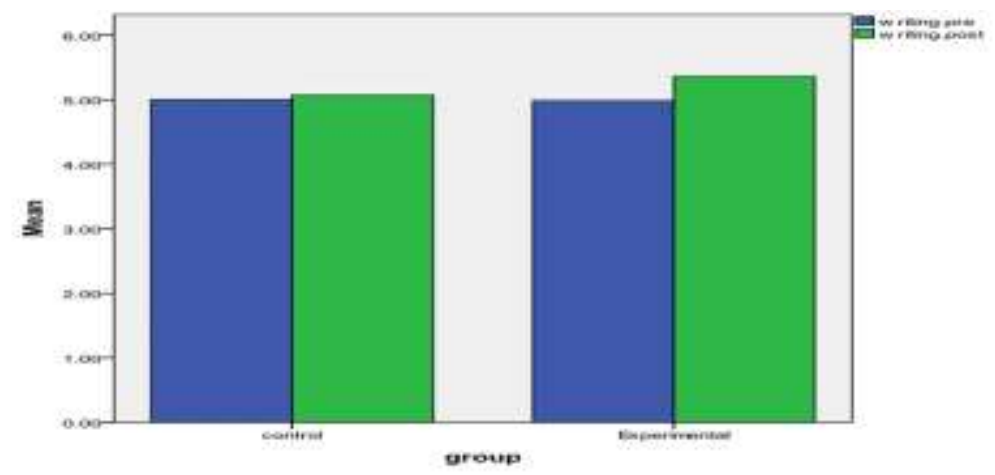


Table 2: The Kolmogorov-Smirnov Test for Checking the Normality of Scores

\begin{tabular}{llllll}
\hline One-Sample Kolmogorov-Smirnov Test & & & & \\
\hline Group & & Speaking.pre & Speaking.post & Writing.pre & Writing.post \\
Control & Kolmogorov-Smirnov Z & .91 & 1.0 & .96 & 1.22 \\
& Asymp. Sig. (2-tailed) & .37 & .26 & .30 & .10 \\
\hline Experimental & Kolmogorov-Smirnov Z & 1.26 & 1.35 & 1.30 & 1.32 \\
& Asymp. Sig. (2-tailed) & .08 & .051 & .06 & .06 \\
\hline
\end{tabular}

Table 3: T-test for Speaking and Writing in Pre and Post-Test

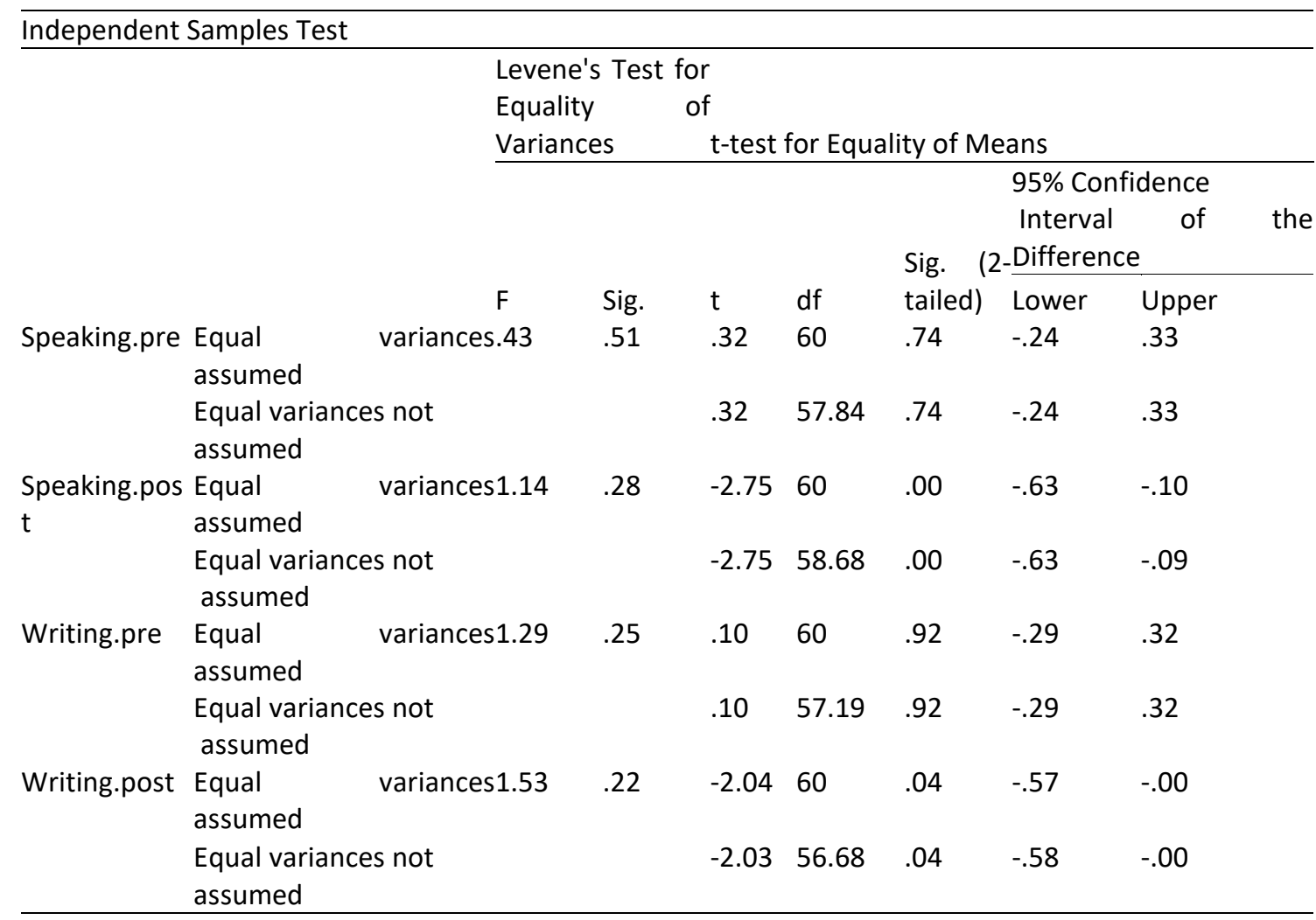

To compare the scores of experimental and control groups, t-test was run. Based on Levine's test findings, the level of significance for the variance of the two groups is .51 for the pre-test of speaking, more than .05; therefore, it is indicated that the two groups are of equal variance. In the pre-test of speaking, the obtained level of significance for the means of the two groups is .74, bigger than .05 , so it can be inferred that there is no significant difference in the pre-test of speaking in both control and experimental group.

Moreover, the two groups show equal variance in the post-test of speaking based on the Levene's test of equality of variance. In the post-test of speaking, the obtained value for the means of the two groups is .00, smaller than .05, which shows a significant difference between the post-test of speaking in control and experimental group.

Considering pre-test of writing, the level of significance for the variance of the two groups was .259, more than .05; thus, the variance of the two groups is equal. Furthermore, in pre-test of writing, the level of significance is .520, less than .05; therefore, the difference between the control and experimental group was not significant. In addition, considering the post-test of writing, the level of significance for the variance of the two groups was .221, more than.05; consequently, the variance of the two groups is equal. The level of significance for the means of the two groups in the post-test of writing is .045, less than .05; therefore, the difference between control and experimental group was not significant. 
Table 4: Comparing the Scores of Speaking and Writing in Pre and Post-Test in Each Group

\begin{tabular}{|c|c|c|c|c|c|c|c|c|}
\hline \multicolumn{9}{|c|}{ Paired Samples Test } \\
\hline \multirow[t]{3}{*}{ Group } & & & \multicolumn{3}{|c|}{ Paired Differences } & \multirow{3}{*}{$\begin{array}{l}\text { I } \\
\text { t } \\
\end{array}$} & \multirow[b]{3}{*}{$\mathrm{df}$} & \multirow[b]{3}{*}{ Sig. (2-tailed) } \\
\hline & & & \multirow[b]{2}{*}{ Mean } & \multicolumn{2}{|c|}{$\begin{array}{l}95 \% \text { Confidence Interval } \\
\text { of the Difference }\end{array}$} & & & \\
\hline & & & & Lower & Upper & & & \\
\hline \multirow[t]{2}{*}{ Control } & Pair 1 & $\begin{array}{l}\text { speaking.pre - } \\
\text { speaking.post }\end{array}$ & -.15 & -.38 & .08 & -1.30 & 29 & .20 \\
\hline & Pair 2 & $\begin{array}{l}\text { writing.pre - } \\
\text { writing.post }\end{array}$ & -.06 & -.28 & .15 & -.62 & 29 & .53 \\
\hline \multirow[t]{2}{*}{ Experimental } & Pair 1 & $\begin{array}{l}\text { speaking.pre - } \\
\text { speaking.post }\end{array}$ & -.56 & -.65 & -.47 & -12.93 & 31 & .00 \\
\hline & Pair 2 & $\begin{array}{l}\text { writing.pre - } \\
\text { writing.post }\end{array}$ & -.37 & -.61 & -.13 & -3.21 & 31 & .00 \\
\hline
\end{tabular}

According to table 4, comparing speaking scores, the difference between pre and post-test in the control group is not significant. Considering writing scores in the control group, in both pre-test and post-test, the level of significance is .536 and above .05; therefore, no significant difference between pre and post-test of writing in the control group is inferred.

This table also presents the level of significance for comparing speaking scores in the pre-test and post-test of the experimental group, which is .000 and below .05 . Based on this result, in the experimental group, there is a significant difference between pre and post-test of speaking. Also, the level of significance for comparing writing scores in pre-test and post-test of the experimental group is .003 and is less than .05 . Thus, in the experimental group, there is a significant difference between pre and post-test of writing.

\section{Discussion}

The present study aimed at delving into the possible influences of EBLI on productive skills (speaking and writing) among Iranian EFL learners. The results indicated that emphasis on vocabularies with a higher amount of emotioncy and the role of affective factors would enhance language learning and teaching, especially productive skills. According to the findings, significant development was shown both in speaking and writing skills in the experimental group in comparison to the control group, which although displayed some development, it was not statistically significant. In this investigation, it was attempted to choose vocabularies based on Pishghadam Metric (2016) and incorporate activities to encourage learners to engage in different activities emotionally. The findings demonstrated that involving the learners in the intake of receptive vocabulary use in EBLI can enhance productive vocabulary use and consequently progress in speaking and writing. This is in accord with the findings of some previous studies which emphasize the role of emotions and El on the development of language skills. For instance, Soodmand Afshar and Rahimi (2016) studied the interplay among reflective thinking, emotional intelligence (EI), and speaking ability in Iranian EFL learning context. According to their results, El is a significantly strong predictor of speaking ability. In another survey by Khooei (2014), the relation of emotional intelligence to oral task fluency, accuracy, and complexity among Iranian EFL learners was investigated. Based on this study, there is a positive relationship between El and oral task accuracy, fluency, as well as complexity among Iranian EFL learners. The outcomes of this study also confirmed the findings of a recent study on the influence of applying emotion-based language instruction in teaching oral skills to EFL university students (Heydarnejad, Ebrahimi, \& Adel, 2019). This research revealed significant improvement both in speaking and listening skills in the experimental group due to the effects of EBLI. Furthermore, some empirical research like that of Genç et al. (2016) is supported by the present study. They showed a positive and close relation between EQ and productive language skills. The obtained result is also in line with that of Makiabadi et al. (2019), who supported a significant positive correlation between all three types of sensory emotioncy and the subscales of WTC as an avenue to EFL learning achievement. Furthermore, the current research provides solid evidence for Brand's theory (1989), who theorized that writing skill is determined by emotions in all processes, from beginning to the final product. Based on this theory, writing is an affective as well as a cognitive process and can be progressed when their intertwined relationships are attended. Actually, writing is an intricate task requiring the concurrent amalgamation of various strategies and different mental resources (Mason, Harris, \& Graham, 2011). It is a complicated and demanding skill calling for more attention, particularly in second/ foreign language context. Considering the importance of writing in sharing beliefs, thoughts, and feelings (Samanian \& Roohani, 2018), it is crucial to remove some of these obstacles, which concluded to was successfully done through EBLI in the present experimental study. 
In line with the findings of the present study, Horwitz, Horwitz, and Cope (1986) indicated that learners with higher levels of writing anxiety write shorter compositions while pleasant emotions like motivation, engagement, and hope generate more ideas and facilitate the ability of elaboration both in speaking and writing. In a foreign language learning context, learners may experience anxiety, which is characterized by worry and feelings of uneasiness. It might be best, therefore, to apply EBLI, which could capture the dynamic nature of affect and change this anxious and stressful situation. In EBLI, every factor which may influence learners' emotions is conspired to provide a secure environment for optimal learning. Also, considering the fact that emotions are influential in cognitive processes such as perception and memory (Parkinson et al., 1996), and bearing in the mind that in a classroom, learners experience different emotions (Pekrun, 2014, p. 6), caring language learners' emotional health is of great importance. As Mogg and Bradley (1999) stipulated, stimulus associated with emotions is remembered better than stimulus, which is unemotional. Moreover, intense emotions enhance memory to remember more details (Heuer \& Reis berg, 1992). These findings are compatible with the main aim of EBLI, which emphasizes the crucial part of emotions in the whole process of teaching and learning. In other words, EBLI, as a new perspective in language teaching, accentuates the role of senses as information channels connecting individuals to the social and physical environment (Pishghadam \& Shayesteh, 2017). In effect, learning especially, language learning must be considered, as an emotional endeavor.

\section{Conclusion}

This study was an attempt to contribute to the sparse knowledge on EBLI and its possible influence on speaking and writing skills among EFL learners. Taken together, the results of the current study led to this conclusion that considering learners' emotions along with their progress in cognition and metacognition is critical in the process of successful language learning and teaching. The implications of the findings may redound to the benefit of teacher educators, curriculum developers, policymakers, material developers, researchers, as well as EFL teachers. This paper, also provides curriculum developers and policymakers with a new window into developing and implementing EBLI approach in L2 learning in particular at university. It is suggested to provide EFL teachers the knowledge and materials necessary to implement EBLI in their classes by preservice/in-service teacher training programs, as well as teacher training courses (TTC). Furthermore, recent studies have indicated that EFL teachers' emotions are directly related to their teaching success (Chen, 2019); therefore, it is recommended to make teachers aware of the benefits of critically and reflectively investigation of their emotional experiences during teaching experiences and seek ways to raise their emotional competencies. Likewise, it is suggested to make learners aware of the advantages of emotion regulation, $E Q$, emotioncy of vocabularies, and reflectivity to maximize learner engagement with language learning (Davoudi \& Heydarnejad, 2020) and upgrade the final outcome. Such awareness may help to develop autonomous learners responsible for their own education. For further research, this study can be replicated with a broader population from different socio-cultural backgrounds to ensure generalizability.

Funding : This research received no external funding.

Acknowledgments : The authors would like to extend their sincere gratitude to University of Gonabad and all the EFL students from this university, who participated in the present study. The authors also wish to thank the respected editors and reviewers for their constructive comments and suggestions.

Conflicts of Interest : The authors declare that they have no conflict of interest.

\section{References}

[1] Baleghizadeh, S. (2016). Materials Development for English Language Teachers: A Practical Guide (4 th Ed.). SAMT.

[2] Brand, A. G. (1989). The psychology of writing: The affective experience. Greenwood.

[3] Brown, H.D. (2007). Principles of language learning and teaching (5 $5^{\text {th }}$ Ed.). Pearson Education.

[4] Chastain, K. (1998). Developing second language skills (2 nd Ed.). Harcourt Brace Publishers.

[5] Chen, J. (2019). Research Review on Teacher Emotion in Asia between 1988 and 2017: Research Topics, Research Types, and Research Methods. Frontiers in Psychology. 10, 1-16. DOI: 10.3389/fpsyg.2019.01628

[6] Cheung, Y. L. (2016). Teaching Writing. In W. A. Renandya, \& H. P. Widodo (Eds.), English Language Teaching Today: Building a Closer Link Between Theory and Practice. New York, NY: Springer International.

[7] Davoudi, M. \& Heydarnejad, T. (2020). The Interplay between Reflective Thinking and Language Achievement: A Case of Iranian EFL Learners. Language Teaching Research Quarterly, 18, 70-82.

[8] Decarrico, J. S. (2001). Vocabulary Learning and Teaching. Celce-Murcia, M. (Ed.). Teaching English as a Second or Foreign Language, pp. 285-299. Boston: Heinle \& Heinle.

[9] Dörnyei, Z., \& Ushioda, E. (2013). Teaching and researching motivation. Routledge.

[10] Ebrahimi, M. R., Khoshsima, H., Behtash, E.Z., \& Heydarnejad, T. (2018). Emotional Intelligence Enhancement Impacts on Developing Speaking Skill among EFL Learners: An Empirical Study. International Journal of Instruction, 11(4), 625-640. https://doi.org/10.12973/iji.2018.11439a 
[11] Febrilia, I., Warokka, A., \& Abdullah, H. H. (2011). University students' emotional state and academic performance: New insights of managing complex cognitive. Journal of e-Learning and Higher Education, 2011 , Article ID 879553. http://dx.doi.org/10.5171/2011.879553

[12] Gairns, R. \& Redman, S. (1986). Working with words: A guide to teaching and learning vocabulary. Cambridge University Press.

[13] Genç, G., Kulusaklı, E., \& Aydın, S. (2016). The relationship between emotional intelligence and productive language skills. The Reading Matrix: An International Online Journal. 16(1), 91-105.

[14] Greenspan, S. I. (1992). Infancy and early childhood: The practice of clinical assessment and intervention with emotional and developmental challenges. Madison, CT: International Universities Press.

[15] Greenspan, S.I. \& Lewis, D. (2005). The affect-based language curriculum: an intensive program for families, therapists, and teachers ( $2^{\text {nd }}$ Ed.). Bethesda, MD: Interdisciplinary Council on Developmental and Learning Disorders (ICDL).

[16] Greenspan, S.I., \& Shanker, S. (2004). The first idea: how symbols, language, and intelligence evolved from our primate ancestors to modern humans. Da Capo Press, Perseus Books.

[17] Gupta, D. \& Woldemariam, G. S. (2011). The influence of motivation and attitude on writing strategy use of undergraduate EFL students: Quantitative and qualitative perspectives. Asian EFL Journal, 13(2), 34-89. Retrieved September 5, 2011, from http://www.asian-efljournal.com/PDF/June 2011.pdf

[18] Harmer, J. (2007). The practice of English language teaching. (4 $4^{\text {th }}$ Ed.). Longman.

[19] Heuer, F., \& Reisberg, D. (1990). Vivid memories of emotional events: The accuracy of remembered minutiae. Memory and Cognition, $18,496-506$.

[20] Heydarnejad, T., HosseiniFatemi, A., \& Ghonsooly, B. (2017). An Exploration of EFL Teachers' Teaching Styles and Emotions. Journal of Applied Linguistics and Language Research, 4(2), 26-46.

[21] Heydarnejad, T., Ebrahimi, M. R., \& Adel, S. M. R. (2019). The Influence of Applying Emotion Based Language Instruction in Teaching Oral Skills to EFL Learners. International Journal of Instruction, 12(2), 275-288. https://doi.org/10.29333/iji.2019.12218a.

[22] Hidayati, K. H. (2018). Teaching Writing to EFL Learners: An Investigation of Challenges Confronted by Indonesian Teachers, 4(1), 21-31.

[23] Horwitz, E. K., Horwitz, M. B. \& Cope, J. (1986). Foreign language classroom anxiety. The Modern Language Journal, 70(2), 125-132. http://dx.doi.org/10.1111/i.1540-4781.1986.tb05256.x

[24] Isen, A.M., \& Patrick, R. (1983). The effect of positive feelings on risk-taking: When the chips are down. Organizational Behavior and Human Performance, 31, 194-202.

[25] Ismail, N. M. (2015). EFL Saudi students' class emotions and their contributions to their English achievement at Taif University. International Journal of Psychological Studies, 7(4), 19-42. http://dx.doi.org/10.5539/ijps.v7n4p19

[26] Jajarmi, H. \& Pishghadam, R. (2019). Emotioncy-Based Language Instruction: A Key to Enhancing EFL Learners' Vocabulary Retention. Applied Research on English Language, 8(2), 207-226. DOI: 10.22108/are.2019.114399.1388

[27] Khooei, S. (2014). Emotional intelligence and its relation to oral task fluency, accuracy, and complexity among Iranian EFL learners. International Journal of Language Learning and Applied Linguistics World, 6(2), 67-93.

[28] Leki, I. (1991). Twenty-Five Years of Contrastive Rhetoric: Text Analysis and Writing Pedagogies. TESOL Quarterly, 25, $123-143$.

[29] Makiabadi, H., Pishghadam, R., Naji Meidani, E., \& Khajavy, G. H. (2019). Examining the role of emotioncy in willingness to communicate: A structural equation modeling approach. Revista de Psicodidáctica, 24(2), 120-130.

[30] Mason, L. H., Harris, K. R., \& Graham, S. (2011). Self-regulated strategy development for students with writing difficulties. Theory into Practice, 50(1), 20-27.

[31] Méndez Lopez, M. G., \& Pea Aguilar, A. P. (2013). Emotions as learning enhancers of foreign language learning motivation. Profile, 15(1), 109-124. http://www.scielo.org.co/pdf/prf/v15n1/v15n1a08.pdf

[32] McArthur, L. A., Kiesler, C. A., \& Cook, B. P. (1969). Acting on an attitude as a function of self-percept and inequity. Journal of Personality and Social Psychology, 12(4), 295-302. DOI: 10.1037/h0027789

[33] McLeod, S. (1987). Some thoughts about feelings: The affective domain and the writing process. College Composition and Communication, 38(4), 426-435.

[34] Mogg, K., \& Bradley, B. P. (1999). Some methodological issues in assessing attentional biases for threatening faces in anxiety: A replication study using a modified version of the probe detection task. Behavior Research and Therapy, 37, 595-604.

[35] Nation, I. S. P. (2009). Teaching ESL/EFL Reading and Writing. Routledge.

[36] Nation, I. S. P. \& Newton, J. (2009). Teaching ESL/EFL Listening and Speaking. Routledge.

[37] Parkinson, B., Totterdell, P., Briner, R. B. \& Reynolds, S. (1996). Changing moods: The psychology of mood and mood regulation. Longman.

[38] Pekrun, R. (2014). Emotions and learning. Gonnet Imprimeur.

[39] Pishghadam, R. (2009). Emotional and verbal intelligences in language learning. Iranian Journal of Language Studies, 3, $43-64$.

[40] Pishghadam, R. (2015). Emotioncy in language education: From exvolvement to involvement. Paper presented at the 2 nd Conference of Interdisciplinary Approaches to Language Teaching, Literature, and Translation Studies. Iran, Mashhad.

[41] Pishghadam, R. (2016). Introducing emotioncy tension as a potential source of identity crisis. Paper presented at the 16th Interdisciplinary Conference on Cultural Identity and Philosophy of the Self, London, England.

[42] Pishghadam, R., \& Abbasnejad, H. (2016). Emotioncy: A potential measure of readability. International Electronic Journal of Elementary Education, 9(1), 109-123.

[43] Pishghadam, R., \& Abbasnejad, H. (2017). Introducing emotioncy as an invisible force controlling causal decisions: A case of attribution theory. Polish Psychological Bulletin, 48(1), 129-140. DOI: 10.1515/ppb-2017-0016 
[44] Pishghadam, R., Adamson, B. \& Shayesteh, Sh. (2013). Emotion-based language instruction (EBLI) as a new perspective in bilingual education. Multilingual Education, 3(9), 1-16. http://dx.doi.org/10.1186/2191-5059-3-9

[45] Pishghadam, R., Jajarmi, H., \& Shayesteh, Sh. (2016). Conceptualizing sensory relativism in light of emotioncy: A movement beyond linguistic relativism. International Journal of Society, Culture \& Language, 4(2), 11-21.

[46] Pishghadam, R., Seyednozadi, Z., \& Zabetipour, M. (2017). Examining teacher credibility and language achievement in light of emotionalization and life syllabus. Int. J. of Pedagogies \& Learning, 12(2), 117-131.

[47] Pishghadam, R., \& Shayesteh, Sh. (2017). Emo-Sensory Expression at the Crossroads of Emotion, Sense, and Language. International Journal of Society, Culture \& Language, 5(2), 15-25.

[48] Pishghadam, R., \& Shayesteh, Sh. (2016). Emotioncy: A post-linguistic approach toward vocabulary learning and retention. Sri Lanka Journal of Social Sciences, 39(1), 27-36. DOI: 10.4038/sljss. v39i1.7400

[49] Pishghadam, R., Shayesteh, Sh., \& Rahmani, S. (2016). Contextualization-emotionalization interface: A case of teacher effectiveness. RIMCIS: Revista Internacionaly Multidisciplinar en Ciencias Sociales, 5(2), 97-127.

[50] Pishghadam, R., Tabatabaeyan, M. S., \& Navari, S. (2013). A critical and practical analysis of first language acquisition theories: The origin and development. Ferdowsi University of Mashhad Publications.

[51] Samanian, S., \& Roohani, A. (2018). Effects of Self-Regulatory Strategy Development on EFL Learners' Descriptive Writing and Reflective Thinking. Research in English Language Pedagogy. 6(1), 95-116.

[52] Schutz, P. A., \& Pekrun, R. (Eds.). (2007). Emotion in education. Elsevier.

[53] Shahian, L., Pishghadam, R. \& Khajavy, G. H. (2017). Flow and reading comprehension: Testing the mediating role of emotioncy. Issues in Educational Research, 27(3), 527-549. http://www.iier.org.au/iier27/shahian.html

[54] Shanker, S., \& Greenspan, SI. (2005). The role of affect in language development. Theoria. 59, 329-343.

[55] odmand Afshar, H. \& Rahimi, M. (2016). Reflective thinking, emotional intelligence, and speaking ability of EFL learners: Is there a relation? Thinking Skills and Creativity, 19, 97 -111. doi.org/10.1016/j.tsc.2015.10.005

[56] Vygotsky, LS. (1978). Mind and society: the development of higher psychological processes. Harvard University Press.

[57] Widdowson, H. (1978). Teaching language as communication. London. Oxford University Press.

[58] Yavuz-Erkan, D. \& Iflazoğlu-Saban, A. (2011). Writing performance relative to writing apprehension, self-efficacy in writing, and attitudes towards writing: A correlational study in Turkish tertiary-level EFL. Asian EFL Journal, 13(1), 164-192. Retrieved September 5, 2011, from http://www.asian-efl-journal.com/PDF/March-2011, pdf 